\title{
Ijtihad and Renewal
}

Said Shabbar
Herndon, VA: The International Institute of Islamic Thought, 2017.
146 pages.

Ijtihad and Renewal is a confessional manifesto by Moroccan scholar and jurist, Said Shabbar. Very much in the style and substance of Taha Jabir al-Alwani, Abd al-Majid Najjar, and other leading lights of the International Institute of Islamic Thought, Shabbar adds a slightly more conservative and, if I may add, an Arab touch to the wider renewal discourse of this milieu.

The intended audience of this monograph is no doubt a wide Muslim readership, most of whom have little background in Islamic jurisprudence (fiqh) and even less in its legal theory literature (ușūl al-fiqh). So this abridged version of Said Shabbar's longer volume minus any footnotes makes his material much more accessible to the general Muslim public. Nancy Roberts' translation is mostly excellent and very readable (I did have some questions however about two sentences that were likely either misleading or at least unclear).

Then too, the book's outline and chapter progression was logical and easy to follow. Of the four sections, the first deals with some "pivotal terms and concepts" used in contemporary renewal discourse; the second continues this vein with an examination of tajdid (renewal), taqlid (imitation), and $i t t i b \bar{a}$ (adherence). Section Three looks at the issue of authority, both its sources (Qur'an and Sunna), and who manages their interpretation (the umma); then also the legitimacy (marja'iyya) of using them as grounds for "innovation and progress"; and in a last section, the scope of the renewal process, which is the global arena. The final three chapters address "the foundations of ijtihad-related thought as it pertains to reform and revival movements and the factors underlying their failures." Thus Section Four is Said Shabbar's application of his research, or his prescription for the renewing of the Muslim mind in this day and age.

The first three sections, then (eight chapters out of eleven), form the bulk of the book as well as its foundation. All these key Arabic terms are helpfully discussed, their various meanings in the Arabic dictionaries given, and their various appearances in the Qur'an discussed. Throughout these pages too, Shabbar quotes a number of classical jurists, while adding throughout the opinion of more recent ones, starting from the early nineteenth-century Muhammad al-Shawkani to Yusuf al-Qaradawi (b. 1926), 
to lesser known ones like the Saudi Shaykh Abd Allah ibn Abd al-Muhsin al-Turki (b. 1940) or the Palestinian Islamist Munir Shafiq (b. 1934). Though he does reference Arab historians, a couple philosophers (Hasan Hanafi and Mohammed Arkoun), and at least one sociologist, this book is mostly the work of a traditional a'lim (jurist and scholar of the Islamic sciences), who leans heavily on the philology of Qur'anic vocabulary and the writings of the classical jurists. That he does so in a clear and helpful way is a boon to the reader who wants to understand and make her own the rich Islamic heritage.

Besides the many quotes (some quite quite long) from dozens of classical and contemporary jurists and thinkers, Shabbar is at his best, I believe, when for example at the beginning of Chapter 6 he offers five meanings for the uses of the word umma in the Quran and then launches into a commentary on its first meaning, "an entity that consists of peoples, clans, tribes and so on in regions all over the globe who are united not by nationality but by shared doctrinal beliefs and a commitment to the Islamic law and practices, customs and values" (80). Uncharacteristically, these first four pages reference the opinion of only one scholar, Majid Ursan al-Kilani (1932-2015), who considers that " $\mathrm{t}]$ he principle element of the concept of ummah is that of its message, that is, what a group of people offers to other human collectivities" (80). He goes on to show what he sees as the three features of this umma in the Qur'an (moderation, chosenness, and testing), and he then teases out the overlapping meanings of this concept in relation to the modern word most used for nation in the political sense, dawla. In the end, this Muslim umma which stretches across the globe strives to balance its objective character derived from the unchanging Islamic message with its great historical, ethnic, and cultural diversity.

Shabbar's message, however, is not so simple to uncover. The above example was an exception, as he mostly speaks through the scholars he brings up. It is difficult, for instance, to find summaries of his own position, say, at the end of chapters where one would expect them. What is clear, though, is that for him ijtihäd today is much more than simply about the finer points of Islamic law, though in all cases it always has to be closely tied to the authoritative texts, Qur'an and Sunna. Whereas the Qur'an has both definitive and speculative texts, the Sunna has those too, but in addition, each text has to be investigated to see to its authenticity (or attestation). Ijtihäd is the process of applying those principles found in the sacred texts to the world as it really is. In his words, "Ijtihad is by definition a process that interacts with concrete circumstances and with newly arising issues and situations" (51). 
Then, following Munir Shafiq, he notes areas about which Muslims urgently need to engage this process of ijtihäd:

1. Enabling Muslims to regain their autonomy from foreign oppression;

2. Healing the divisions among Muslims worldwide;

3. Eradicating poverty;

4. Spurring economic development;

5. Improving governance by fostering more consultation and social justice;

6. Cleaning up the pollution of water and air, and meeting the wider challenges of environmental degradation;

7. Reducing the debt of the poorest nations;

8. Bringing wholeness back to families on the verge of "disintegration and collapse."

After presenting this long list, Shabbar admits that it will "be a major challenge to agree collectively on the overall features of an approach to ijtihad and renewal." He then adds, "However, it is reasonable to believe that we can reduce differences of opinion and work effectively in this direction" (51). Yet nowhere does he suggest how this might happen, or on what level or context of leadership this might be tackled.

One thing is clear about Shabbar's perspective, however: he holds to an Islamist worldview. The two authors most quoted in the book are Hasan al-Turabi and Yusuf al-Qaradawi. While discussing Qaradawi's views on religious renewal, Shabbar avers that " $[\mathrm{w}]$ hen we renew something ... our aim is ... to restore it to its original state" (48). So in this conservative framework, "intellectual renewal ... involves rediscovering and developing already existing ideas in keeping with the needs prevalent in our times, and based on relevant rules, methodologies, and recognized constants" (48-49). And then, when scholars and leaders have deliberated together and come up with practical solutions to the problems of the day, "it is the state's responsibility to codify the outcomes of this consultation into specific rulings and laws within the context of its pre-existing structures" (84).

In Chapter 9, when dealing with the Arab nationalist movement in the postcolonial era, his main point is that its secularist ideology was responsible for its failure. For those ruling elites socialism had become a religion as well as a tool for oppressing the masses. In that context, he argues, Hasan al-Banna and the Muslim Brotherhood are the rightful heirs to the Salafi reform movement of al-Afghani and Muhammad Abduh. For al-Banna, "the more Arabism distances itself from secularism, the closer 
it is to Islam" (105). The chapter ends with a prolonged attack on secularism (110-115). For Shabbar, Islam is a religion "which is based largely on legislation that provides a foundation for society" (114). Then he adds, "Shaykh Muhammad Abduh went so far as to say that separating religion from the state is not only undesirable; it is impossible" (115). Religion must be "established" (as in Q 2:43) by the governing authorities.

As I see it, Said Shabbar only pays lip service to the importance of consulting the social sciences while seeking to renew Muslim thought today. The only sociologist he quotes is the Syrian scholar who has taught for many years in Paris, Burhan Ghalioun, and it is mainly to support his own leaning toward political Islam. On the other hand, I was taken aback to see him agree with the Tunisian scholar Ibn 'Ashur's explanation for why the Qur'anic revelation first came to the Arabs: "(1) good minds, (2) powerful memories, (3) a simple civilization and legislative code; and (4) relative isolation from other peoples of the world" (94). Somehow Arabs were thereby qualified "to receive, understand, preserve and convey the message of Islam." Then this quasi-theological statement: "Being closer than other peoples to pristine human nature, the Arabs were well suited to imbibe the moral teachings of Islam." I have read this kind of statement before, but in this context it strikes me as incongruous with an informed sociological perspective.

In addition, Shabbar quotes al-Banna on some of the major causes for the decadence of the Islamic civilization. Among the six causes he lists is "the transfer of power and leadership to non-Arabs, including the Persians, the Mamluks, the Turks and others, none of whom had a proper understanding of Islam" (120). This is particularly troublesome, because Shabbar only quotes Arabs in the modern period (al-Ghazali, of course, was a Persian, as many of the leading Islamic scholars of the classical period were non-Arabs). As we all know, there are many wonderful reformist publications in other parts of the world.

Also rather inconveniently, Shabbar does not quote even one woman, which is particularly ironic, considering that his compatriot, the late sociologist Fatima Mernissi, was a creative and brilliant writer on the renewal of Islamic thought, especially in the field of gender studies. Still, as a primer on the historical sources of ijtihād and on how one Arab scholar sees Islamic renewal today, this is a useful read. 